\title{
ORBITOLINIDS AND OTHER LARGER BENTHIC FORAMINIFERA FROM THE APTIAN-ALBIAN OF TIBET: CRITICAL DISCUSSION OF SOME RECENTLY PUBLISHED DATA
}

\author{
Felix Schlagintweit
}

Received: 11 July 2021 / Accepted: 5 September 2021 / Published online: 9 September 2021

\begin{abstract}
Orbitolinidae together with other larger benthic foraminifera are particularly important in Lower Cretaceous shallow-water biostratigraphy provided that they are correctly identified. Especially in the case of the Orbitolininae (with complex embryo), their biostratigraphic range with overlapping ranges corresponds to different lineages displaying ancestor-descendant relationship (e.g., Praeorbitolina-Mesorbitolina). In the last fifty years well established and repeatedly confirmed taxon ranges have been largely extended thereby diluting or negating any biostratigraphic value to individual species. Some biostratigraphic data provided by BouDagher-Fadel et al. (2017) from the AptianAlbian of Tibet that are contradicting previous results are reviewed herein. This publication mostly refers to the stratigraphic ranges of Praeorbitolina cormyi Schroeder and Pseudochoffatella cuvillieri Deloffre towards the top of the Albian, and that of Palorbitolina lenticularis (Blumenbach) into the late Aptian, as well as some misidentifications.
\end{abstract}

Keywords: Lower Cretaceous, Orbitolinidae, taxonomy, biostratigraphy

\section{INTRODUCTION}

Orbitolinidae together with other larger benthic foraminifera are particularly important in the Lower Cretaceous shallow-water limestones microbiostratigraphy. The biostratigraphical distribution framework of the representatives of this foraminiferal group and especially the Orbitolininae that present a complex embryo is wellestablished since several decades (Schroeder, 1975; Moullade et al., 1985; Schroeder et al., 2010; Cherchi and Schroeder, 2013). In contrast, the stratigraphical ranges of Dictyoconinae that have a morphologically simple embryo is less accurately known. This setting is probably due to the fact that a considerable number of taxa of the Dictyoconinae display a distinct provincialism whereas those of the Orbitolininae have a much wider distribution, cosmopolitan in some cases, and are therefore much more useful for stratigraphic dating and correlations. However, the biostratigraphical value of individual taxa is significantly reduced when incorrect taxonomic determinations are used to extend the known ranges on charts. Such data are often used in formulating new hypotheses on phylogeny, resulting in expanding and refining the existing concepts. Therefore, it is considered important for scientific practical purposes to critically review these data, as exemplified by the numerous reply or comment papers published recently (Consorti \& Schlagintweit, 2020; Granier 2020a, b; Simmons, 2020; Schlagintweit, 2020, 2021; Benedetti, 2021; Schlagintweit \& Bucur, 2021). The following review focuses on some orbitolinids and other larger benthic foraminifera from the Aptian-Albian of Tibet provided by BouDagher-Fadel et al. (2017) in the paper "Foraminiferal biostratigraphy and palaeonvironmental analysis of the Mid-Cretaceous limestones in the Southern Tibetian Plateau" published in Journal of
Foraminiferal Research vol. 47, no. 2, pages 188-207. The extension of the lower Aptian Praeorbitolina wienandsi Schroeder and the upper Aptian-lower Albian Pseudochoffatella cuvillieri Deloffre to the top of the Albian in the Tibet region is critically discussed thereafter. These assumed incorrect "data" could be simply ignored, but the circumstance that they are used to "enabling and refinement of the eastern Tethyan carbonate biostratigraphy" necessitates a wider discussion especially when it also scratches the legacy of highly regarded micropaleontologists.

\section{DISCUSSION}

The orbitolinids recorded by BouDagher-Fadel et al. (2017) are from the Langshan and other formations of the Lhasa Block or terrane that was located "on the northern margin of eastern Tethys Ocean in mid-Cretaceous times" (Rao et al., 2015, p. 401). This information is of importance as many Dictyoconinae display a distinct bioprovincialism ("European" vs. "African" margins of the Neotethys; Cherchi et al., 1981). The orbitolinid fauna of the Lhasa Block have been studied in the past by Zhang (1982, 1986, 1991). The numerous taxa (genera and species) established therein and their assumed junior synonyms have been partly summarized by Schroeder et al. (2010), Rao et al. (2015, tables. 1-2), and BouDagherFadel et al. (2017). The new data critically discussed here include: A) the records of Mesorbitolina parva and Praeorbitolina cormyi, B) the extension of Praeorbitolina cormyi and Pseudochoffatella cuvillieri to the top of the Albian, and C) the extension of Palorbitolina lenticularis into the late Aptian. As BouDagher-Fadel et al. (2017, p. 188) correctly stated these ranges are "not compatible 
with the now widely accepted description of orbitolinids (see Schroeder et al., 2010)".

\section{Record of Mesorbitolina parva (Douglass, 1960)}

(Fig. 1A)

Referred illustrations: Mesorbitolina parva, part of figure 8 in BouDagher-Fadel et al. (2017).

Mesorbitolina parva (Douglass, 1960) has been described as Orbitolina (Columnorbitolina) absidata by Zhang (1986) from the Langshan Formation of the Lhasa Block. Here we make reference to a tiny image of "Mesorbitolina parva" included in Fig. 8 of BouDagher-Fadel et al. (2017) therein showing the stratigraphic ranges and assumed phylogenetic relationships (Fig. 1A). The specimen is here interpreted as an axial section of Praeorbitolina cormyi perpendicular to the median plane comparable to those illustrated by Bosselini et al. (1999, fig. 5a and $5 \mathrm{~g}$ ) from the early Aptian of Ethiopia (Fig. 1B-C), or own material from Iran (Fig. 1D-E). It shows a subdivided subembryonic zone overlain by protoconch and deuterconch; a supraembryonic zone is seemingly lacking. The regular presence of short partitions at the top of the deuteroconch (not well discernible) would indicate Praeorbitolina claveli Schlagintweit et al. This example and the following ones give evidence that the established ranges partly include incorrect determinations too.

Record of Praeorbitolina cormyi Schroeder, 1964 and Praeorbitolina wienandsi Schroeder, 1964

(Fig. 2A-B, E)

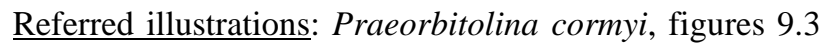
to 9.7 in BouDagher-Fadel et al. (2017). Praeorbitolina cf. wienandsi, figure 12.1 in BouDagher-Fadel et al. (2017).

The specimens of $P$. cormyi illustrated by BouDagherFadel et al. (2017) are low-conical with test diameter of up to $2.3 \mathrm{~mm}$ (Fig. 2A-B). Although no detail of the embryo is provided, in my opinion, it is well discernible that a subapical simple embryo of one or two chambers (= protoconch and deuteroconch or first postembryonic chamber) that lacks a subembryonic zone is present. Such an embryo type is reported from the dictyoconid Paleodictyoconus actinostoma Arnaud-Vanneau \& Schroeder. Examples of comparable specimens from the early Aptian of Iran are shown in Figure 2C-D. The adult specimens illustrated by BouDagher-Fadel et al. (2017, fig. 9.5 and 9.6) show a low conico-concave test morphology (e.g., Henson, 1948, fig. 12i) typical for P. actinostoma. This morphology results from sigmoseptal (in cases annular) adult chambers leading to a striking central depression at the cone base (Arnaud-Vanneau \& Schroeder, 1976; Clavel in Granier et al, 2013, 2017). The principal occurrence of Praeorbitolina cormyi in lower Aptian limestones of the Tibetian area is well rec- orded (e.g., Zhang, 1991) but, in my opinion the specimens illustrated by BouDagher-Fadel et al. (2017) do not belong to this species. The specimen of Praeorbitolina $\mathrm{cf}$. wienandsi (BouDagher-Fadel et al., 2017, fig. 12.1) shows a biloculine embryo (protoconch and deuteroconch) lacking a subembryonic zone in my opinion (Fig. 2E). The specimen from Tibet might belong to Paleodictyoconus sp. (see Fig. 2F-G for comparison). This conclusion provides a revised basis interpretation for the provided biostratigraphic framework therein.

\section{Record of Palorbitolinoides orbiculata Zhang, 1986 and Palorbitolinoides hedini Cherchi \& Schroeder, 1980}

Referred illustration: Palorbitolinoides orbiculata Zhang, figure 8.8, Palorbitolinoides hedini Cherchi \& Schroeder, 1980, figure 8.9 in BouDagher-Fadel et al. (2017).

Both species have been described from Aptian-Albian limestones of Tibet (Cherchi \& Schroeder, 1980; Zhang, 1986). A third species, Palorbitolinoides tenuis Zhang, 1986 , is considered a junior synonym of the type-species $P$. hedini by Schroeder et al. (2010). The differences of both species refer to the size and complexity of the embryo. The diameter of the central embryonic chamber is 0.21-0.4 $\mathrm{mm}$ in P. orbiculata (see Zhang, 1986, table page 207) against $0.45-0.7 \mathrm{~mm}$ in $P$. hedini (see Schroeder et al., 2010, p. 60). The embryo of $P$. hedini is much larger as in $P$. orbiculata, flattened, and with a well developed and inflated peri-embryonic zone. In addition, the partitions at the top of the embryonic chamber produce a system of small alveoli of different lengths. Both specimens illustrated by BouDagher-Fadel et al. (2017) display a hemi-spherical embryonic chamber (diameter $\sim 0.31-\sim 0.39 \mathrm{~mm}$ ) with rather short partitions of seemingly equal length. They are interpreted as belonging to $P$. orbiculata. The stratigraphy of the two species $P$. orbiculata and $P$. hedini appears not as well fixed as other Orbitolininae (Cherchi \& Schroeder, 1980, 2013; Zhang, 1986; Marcoux et al., 1987; BouDagher-Fadel et al., 2017). Transitional types between $P$. orbiculata and $P$. hedini have been illustrated by Marcoux et al. (1987, pl. 2, figs. 2-4) from the late Aptian of Tibet. It is worth noting that representatives of Palorbitolinoides co-occuring with Mesorbitolina aperta (Erman) in the upper Albian of the Kazhdumi Formation in SW Iran are currently under study. Also with respect to the palaeobiogeographic distribution there seems to be some kind of dissens as Cherchi \& Schroeder (2013) considered Palorbitolinoides cf. orbiculata as a typical taxon of the southern Neotethysian margin.

\section{Extension of Praeorbitolina to the top of the Albian} (Fig 2E)

Referred illustration: Praeorbitolina cf. wienandsi, figure 12.1 in BouDagher-Fadel et al. (2017). 


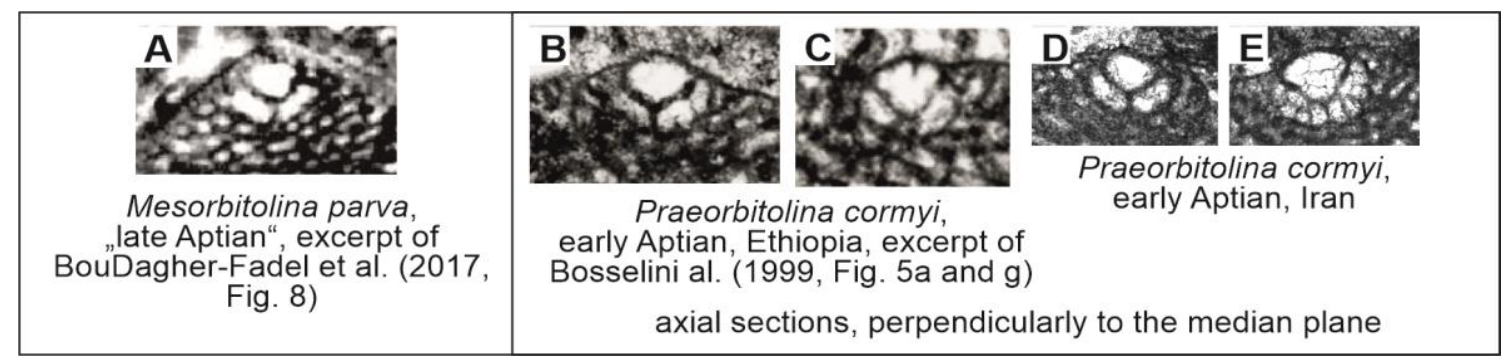

Fig. 1. A, Mesorbitolina parva (Douglass) fide BouDagher-Fadel et al. (2017, excerpt of fig. 8), Lower Cretaceous of Tibet. B-E, Praeorbitolina cormyi Schroeder, axial sections perpendicular to the median plane (B-C: excerpt of Bosselini et al., 1999, fig. 5a and 5g, early Aptian of Ethiopia; D-E: early Aptian of Iran). Figures without scale.

The comparably short range of Praeorbitolina in the upper lower Aptian (upper Bedoulian) has been recorded from all over the Tethysian realm since the description of the species in the sixties (e.g., Schroeder, 1964; Moullade et al. 1985; Cherchi et al., 1999; Schroeder et al., 2010; Schlagintweit et al., 2013). Its stratigraphic distribution has been questioned by BouDagher-Fadel et al. (2017) extending its range to the top of the Albian in the "Tibetian Platform". This assumption is based on an axial section of an orbitolinid showing the megalospheric embryo at the beginning of a small eccentric spire. It shows a spherical embryo and one smaller chamber (deuteroconch or first post-embryonic chamber) partly enclosing the former; a subembryonic zone as typical for the genus is lacking. Comparable sections from the lower Aptian of Iran refer to juvenile specimens of Paleodictyoconus sp. (probably P. actinostoma) (Fig. 2F-G). Thus, there is in my opinion no evidence that Praeorbitolina extends to the top of the Albian, thereby reinstating the lineage Praeorbitolina (late early Aptian)-Mesorbitolina (late Aptian-Albian) (e.g., Schroeder et al., 2010). Only recently the extension of Praeorbitolina into the top of the Aptian has been proposed (Gheiasvand et al., 2020) based on incorrect species identification of associated taxa (see Schlagintweit, 2022 for details). Last but not least, mention should be made that the presence of Paleodictyoconus actinostoma in Tibet fits with the northern Neotethysian orbitolinid assemblages. From the former southern margin of the Neotethys, $P$. actinostoma has far not been recorded.

Extension of Pseudochoffatella cuvillieri to the top of the Albian

Fig. $2 \mathrm{H}$

Referred illustrations: Pseudochoffatella cuvillieri, figures 12.7 and 12.8, figure 9.9 (cf.) in BouDagher-Fadel et al. (2017).

P. cuvillieri Deloffreis typically recorded from the upper Aptian (Busnardo et al., 1968: "biozone à Pseudochoffatella cuvillieri; Fourcade, 1970; Moullade and Peybernès, 1975; Peybernès, 1976; Schlagintweit et al., 2016). In other areas, however, $P$. cuvillieri is recorded also throughout the lower Albian (Granier, 1987; Betic Cordillera, Spain).
With the exception of one record in Switzerland (Schroeder et al., 2007), Pseudochoffatella cuvillieri has only been recorded from Iberia. The three specimens of $P$. cuvillieri illustrated by BouDagher-Fadel (2017) are here considered as belonging to three discrete taxa. The specimen shown in fig. 12.7 therein (here re-illustrated exemplarily in Fig. 2H) represents an uncoiling lituolid with alveolar wall structure, and a single central foramen. Note that Pseudochoffatella possesses reniform to annular chambers, a shallow subepidermal network of beams and rafters and cribrate foramina (Deloffre, 1961, 1976; Cherchi \& Schroeder, 1982; Loeblich \& Tappan, 1987). Comparable specimens have been observed in the early Aptian Taft Formation of Iran (Fig. 2I-K). The specimen illustrated in Fig. 12.8 by BouDagher-Fadel et al. (2017) corresponds to an oblique section of an unknown coarsely agglutinated foraminifera with short coiled portion, then uncoiling, and chambers with coarse subepidermal network (ultimate chamber above). The specimen illustrated in fig. 9.9 by BouDagher-Fadel et al. (2017) corresponds to an oblique equatorial section of a planispirally coiled agglutinated taxon with coarse-alveolar wall. It might belong to Pseudocyclammina (e.g., compare with BouDagher-Fadel et al., 2017, fig. 9.8) but the illustration quality and the uncertainty about the foramina features do not allow a precise identification.

\section{Extension of Palorbitolina lenticularis into the latest late Aptian}

An axial section of $P$. lenticularis with well developed peri-embryonic ring has been illustrated by BouDagherFadel et al. (2017) in fig. 9.1 therein from the upper lower Aptian. The specimen on the basis of which the extension into the latest Aptian and the resulting overlapping range with Mesorbitolina texana (see range chart, fig. 13 therein) has not been illustrated. In the orbitolinid biostratigraphic chart of Schroeder et al. (2010, Fig. 3) P. lenticularis has its LAD at the early-late Aptian (= BedoulianGargasian boundary) while M. texana has its FAD in the late Gargasian. In the absence of illustration and reproducible data such as those of Granier et al. $(2013,2017)$ extending the FAD of $P$. lenticularis into the late early Barremian, the occurrence of Palorbitolina in the upper Aptian in Tibet is doubted herein. During the early 


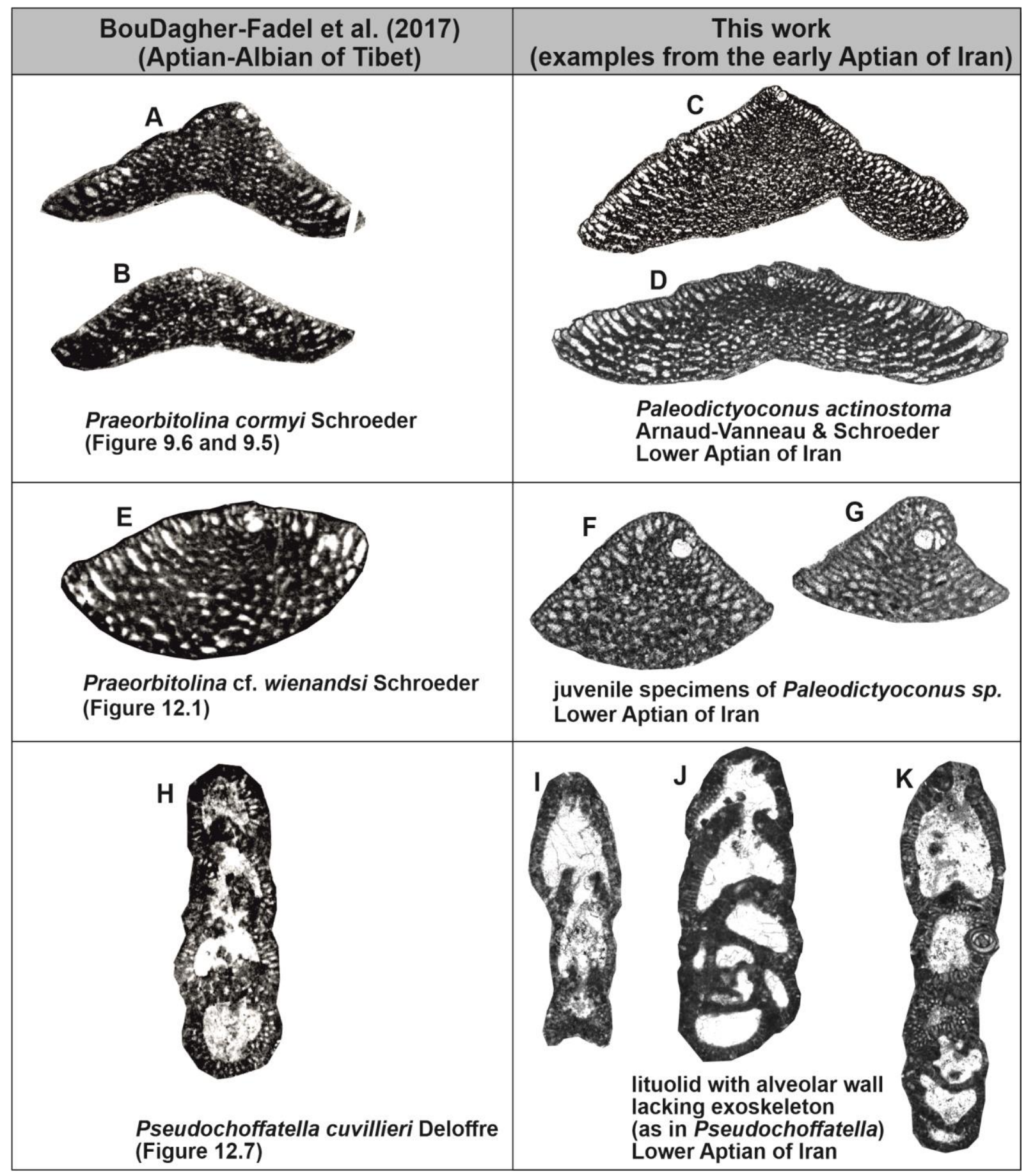

Fig. 2. A-B, Praeorbitolina cormyi Schroeder fide BouDagher-Fadel et al. (2017, fig. 9.6 and 9.5), Lower Cretaceous of Tibet. C-D, Paleodictoyconus actinostoma Arnaud-Vanneau \& Schroeder, early Aptian of Central Iran. E, Praeorbitolina cf. wienandsi Schroeder fide BouDagher-Fadel et al. (2107, fig. 12.1). F-G, juvenile specimens of Paleodictyoconus sp., (?P. actinostoma Arnaud-Vanneau \& Schroeder), early Aptian of Central Iran. H, Pseudochoffatella cuvillieri Deloffre fide BouDagher-Fadel et al. (2017, fig. 12.7). I-K, unknown lituolid, early Aptian Taft Formation of Central Iran. Figures without scale.

Aptian the peri-embryonic ring of Palorbitolina lenticularis shifted more and more towards the base of the proloculus (> Palorbitolina ultima) giving rise to the genus Palorbitolinoides with a subembryonic zone completely enveloping the former in the late early Aptian (Cherchi \& Schroeder, 1980; Schroeder et al., 2010). An occurrence of Palorbitolina in the late Aptian would counteract the phylogenetic lineages (see Schroeder et al., 2010, fig. 3).

\section{CONCLUSIONS}

The Orbitolinidae represent a complex group of larger benthic foraminifera studied in the past by few specialists who dedicated almost their whole focus on deciphering the phylogenetic, taxonomic, and biostratigraphic aspects of this group. Especially, the stratigraphic ranges of the Orbitolininae with complex embryo appear as a rather 
consolidated framework used by researchers world-wide. Small corrections of the ranges of individual taxa appear possible as it has been shown for the FAD of Palorbitolina. Such corrections need well founded data (e.g., ammonite data or other anchors to the chronostratigraphy), and should in any case be discussed in detail against the background of previous data. The extension of both Praeorbitolina and Pseudochoffatella to the top of the Albian in the Tibet region is here rejected because it is not based on solid and reproducible evidences. In addition, the range charts of other taxa (Praeorbitolina wienandsi, Mesorbitolina parva) are at least in part based on seemingly incorrect determinations. There is no evidence that the stratigraphic ranges of Palorbitolina lenticularis and Praeorbitolina cormyi as indicated in the biostratigraphic scheme of Schroeder et al. (2010) need correction. It is hoped that, in the future, especially the "data" resulting in revision of classically biostratigraphic framework will be illustrated with adequate details (magnification, high quality images) allowing verification (or falsification) for subsequent researchers.

\section{ACKNOWLEDGEMENTS}

Helpful comments by reviewers Lorenzo Consorti (Rome), Bruno Granier (Brest) and Mohsen YazdiMoghadam (Tehran) are kindly acknowledged. Koorosh Rashidi (Yazd) is thanked for providing the images of Praeorbitolina cormyi from Iran. Qinghai Zhang (Bejing) is thanked for assistance in translation of Chinese text from parts of Zhang (1986).

\section{REFERENCES}

Arnaud-Vanneau, A. \& Schroeder, R., 1976. Paleodictyoconus actinostoma $\mathrm{n}$. sp. orbitolinidé nouveau des "couches à orbitolines" intra-urgoniennes du Vercors (France). Géobios, 9 (3): 279-289.

Benedetti, A., 2021. Comments on "Larger benthic foraminiferal assemblages and their response to Middle Eocene Climate Optimum in the Kohat Basin (Pakistan, eastern Tethys)" by Kamran et al. Palaeoworld, https://doi.org/10.1016/j.palwor.2020.09.004.

BouDagher-Fadel, M., Hu, X., Price, G.D., Sun, G., Wang, J.-G. \& An, W., 2017. Foraminiferal biostratigraphy and palaeoenvironmental analysis of the mid-Cretaceous limestones in the southern Tibetian Plateau. Journal for Foraminiferal Research, 47 (2): 188-207.

Bosselini, A., Russo, A. \& Schroeder, R., 1999. Stratigraphic evidence for an Early Aptian sea-level fluctuation: the Graua Limestone of south-eastern Ethiopia. Cretaceous Research, 20: 783-791.

Busnardo, R., Champetier, Y., Fourcade, E. \& Moullade, M., 1968. Étude stratigraphique des faciès à Orbitolinidés et à Rudistes de la Sierra Mariola (Province d'Alicante, Espagne). Géobios, 1: 165-185.
Cherchi, A., Durand-Delga, M. \& Schroeder, R., 1981. Apercu paléogéographique sur les provinces à grands Foraminifères du Crétacé inférieur dans le cadre structural méditerranéen. Rapport de la Commission internationale pour l'Exploration de la Mer Méditerranée, 27: 115-119.

Cherchi, A. \& Schroeder, R., 1980. Palorbitolinoides hedini n. gen. n. sp., grand foraminifère du Crétacé du Tibet méridional. Comptes Rendus hebdomadaires des Séances de l'Académie des Sciences, série D. 291: 385-388.

Cherchi, A. \& Schroeder, R., 1982. Précisions sur Pseudochoffatella Deloffre et remarques sur Balkhania balkhanica Mamontova (Foraminifères). Revue de Micropaléontologie, 25: 154-162.

Cherchi, A. \& Schroeder, R., 2013. The Praeorbitolina/Palorbitolinoides association: An Aptian biostratigraphic key-interval at the southern margin of the Neo-Tethys. Cretaceous Research, 39: 70-77.

Cherchi, A., Schroeder, R. \& Bin Ghoth, M., 1999. Early Aptian orbitolinid foraminifera from the Qishn Formation of Al Mukalla (Hadramawt, Southern Yemen). Comparisons with adjacent regions. Zeitschrift für geologische Wissenschaften, 26 (5-6): 543-561.

Consorti, L. \& Schlagintweit, F., 2020. Comment on "Does specialization imply rare fossil records of some benthic foraminifera: Late Palaeocene examples from the eastern Neo-Tethys (Meghalaya, NE India)" by Suman Sarkar [Palaeogeography, Palaeoclimatology, Palaeoecology, 514 (2019) 124-134. Palaeogeogr., Palaeoclimatol., Palaeoecol., 539: 109525.

Deloffre, R., 1961. Sur la découverte d'un nouveau Lituolidé du Crétacé inférieur des Basses-Pyrénées: Pseudochoffatella cuvillieri n. gen., n. sp. Revue de Micropaléontologie, 4 (2): 3-12.

Deloffre, R., 1976. Validation de Pseudochoffatella cuvillieri Deloffre, 1961. Bulletin du Centre de Recherches Pau-SNPA, 10: 35-38.

Douglass, R.C., 1960. The foraminiferal genus Orbitolina in North America. Geological Survey Professional Papers, 333: 1-52.

Fourcade, E., 1970. Le Jurassique et le Crétacé aux confins des chaînes bétiques et ibériques (Sud-Est de 1'Espagne). Thèse d'Ètat, Universié Pierre et Marie Curie, Paris, 427pp.

Gheiasvand, M., Ashouri, A.R., Aghanabati, S.A., Taherpour-Khalil-Abad, M. \& Ghaderi, A., 2020. Stratigraphic distribution of shallow-water benthic foraminifera from the Lower Cretaceous Taft formation, Central Iran (Yazd Block), with evidence for the importance of hiatuses. Annales de Paléontologie, 106 (3): 102399.

Granier, B., 1987. Le Crétacé inférieur de la Costa Blanca entre Busot et Altea, Alicante (Espagne). Biostratigraphie, sédimentologie, évolution tectonosédimentaire. Thèse, Docteur de l'Université Paris VI (nouveau régime), 23 Novembre 1987; Mémoires des Sciences de la Terre, Université Pierre et Marie Curie, 
Paris, 87-49, vol. I (text): 281 pp., 63 figs.; vol. II (plates): 54 pls.

Granier, B., 2020a. Discussion of the paper by Vincent et al., 2018, entitled "Age constraints on intraformational unconformities in Upper Jurassic-lower Cretaceous carboinates in northeast Turkey: geodynamic and hydrocarbon implications" (Marine and Petroleum Geology, 91, 639-657). Marine and Petroleum Geology, 112: 103795.

Granier, B., 2020b. Discussion of the paper by Imad M. Ghafor and Ibrahim M.J. Mohialdeen, 2018, entitled "Early Cretaceous microfossils associations (foraminifera, ostracoda, calcareous algae, and coral) from the Garagu formation, Dukok area, Kurdistan region, northern Iraq" (Arabian Journal of Geosciences, 11: 407). Arabian Journal of Geosciences, 13: 60.

Granier, B., Clavel, B., Moullade, M., Busnardo, R., Charollais, J., Tronchetti, G. \& Desjacques, P. (2013). L'Estellon (Baronnies, France), a "Rosetta Stone" for the Urgonian biostratigraphy. Carnets Géol., 13 (A04), 139-183. https://doi.org/10.4267/2042/51213

Granier, B., Clavel, B., Moullade, M., Busnardo, R., Charollais, J., Tronchetti, G. \& Desjacques, P., 2017. L'Estellon (Baronnies, France), a "Rosetta Stone" for the Urgonian biostratigraphy. In: Granier, B. (Ed.), Some key Lower Cretaceous sites in Drôme (SE France). Association Carnets de Géologie, Madrid, Book 2017/01 (CG2017_B01), ISBN13: 978-2-916733-135, pp. 117-163.

Henson, F.R.S., 1948. Larger imperforate Foraminifera of south-western Asia. Families Lituolidae, Orbitolinidae and Meandropsinidae. Monograph British Museum (Natural History), 127 p.

Gheiasvand, M., Ashouri, A.R., Aghanabati, S.A., Taherpour-Khalil-Abad, M. \& Ghaderi, A., 2020. Stratigraphic distribution of shallow-water benthic foraminifera from the Lower Cretaceous Taft formation, Central Iran (Yazd Block), with evidence for the importance of hiatuses. Annales de Paléontologie, 106 (3): 102399.

Marcoux, J., Girardeau, J., Fourcade, E., Bassoullet, J.E.P., Philip, J.M., Jaffrezo, M., Xuchang, X. \& Chengfa, C., 1987. Geology and biostratigraphy of the Jurassic and lower Cretaceous series to the north of the Lhasa Block (Tibet, China). Geodinamica Acta, 1: 313-325.

Moullade, M., Peybernès, B., Rey, J. \& Saint-Marc, P., 1985. Biostratigraphic interest and paleobiogeographic distribution of early and mid-Cretaceous Mesogean orbitolinids (Foraminiferida). Journal of Foraminiferal Research, 15 (3): 149-158.

Moullade, M. \& Peybernès, B., 1975. Biozonation par Orbitolinidés du Clansayésien et de l'Albien calcaires des Pyrénées francoespagnoles. Comptes Rendus de l'Académie des Sciences, D, 280: 2529-2532.

Peybernès, B., 1976. Le Jurassique et le Crétacé inférieur des Pyrénées franco-espagnoles entre la Garonne et la
Méditerranée. Thèse d'État, Université Paul Sabatier, Toulouse, $459 \mathrm{p}$.

Rao, X., Skelton, P.W., Sha, J., Cai, H.W. \& Iba, Y., 2015. Mid-Cretaceous rudists (Bivalvia: Hippuritida) from the Langshan Formation, Lhasa Block, Tibet. Papers in Paleontoloy, 1 (4): 401-424.

Rat, P., 1963. L'accroissement de taille et les modifications architecturales corrélatives chez les orbitolines. In: Koenigswald, G.H.R. von. et al. (Eds.), Evolutionary Trends in Foraminifera. Elsevier, Amsterdam pp. 93-109.

Schlagintweit, F., 2020. Critical assessment of Sayyabellus Mohammed, 2003 (type-species S. scutulus) orbitolinid foraminifera from the Lower Cretaceous of Iraq. Iranian Journal of Geoscience Museum, 1 (2): 115-119.

Schlagintweit, F., 2022. Comments on "Stratigraphic distribution of shallow-water benthic foraminifera from the Lower Cretaceous Taft Formation, Central Iran (Yazd Block), with evidence for hiatuses" by Gheiasvand, M. et al. [Annales de Paléontologie, 2020, 154 (3), 102399] and related papers. Acta Palaeontologica Romaniae, 18 (1): 3-8.

Schlagintweit, F. \& Bucur, I.I., 2021. The late Berriasian early evolutionary burst of the Orbitolinidae: New insights into taxonomy, origin, diversification and phylogeny of the family based on data from eastern Serbia. Carnets Geol., 21 (15): 343-382. DOI 10.2110/carnets.2021.2115

Schlagintweit, F., Rosales, I. \& Najarro, M., 2016. Glomospirella cantabrica n. sp., and other benthic foraminifera from Lower Cretaceous Urgonian-type carbonates of Cantabria, Spain. Geologica Acta, 14 (2): 113-138.

Schroeder, R., 1964. Communication préalable sur l'origine des Orbitolines. Compte Rendu sommaire des Séances de la Société géologique de France, 10: 411-413.

Schroeder, R., 1975. General evolutionary trends in orbitolinas. Revista Española de Micropaleontologia, Num. esp. 1975: 117-128.

Schroeder, R. \& Neumann, M., coords., 1985. Les Grands Foraminifères du Crétacé moyen de la région méditerranénne. Géobios, Mémoire Spécial, 7: 1-161.

Schroeder, R., Clavel, B., Cherchi, A., Busnardo, R., Charollais, J. \& Decrouez, D., 2002. Lignées phylétiques d'Orbilolinidés dans Hauterivien supérieur Aptien inférieur du Sud-Ouest de l'Europe et leur importance stratigraphique. Revue de Paléobiologie, 21: 853-863.

Schroeder, R., Buchem, F.S.P., van, Cherchi, A., Baghbani, D., Vincent, B., Immenhauser, A. \& Granier, B., 2010. Revised orbitolinid biostratigraphic zonation for the Barremian-Aptian of the eastern Arabian Plate and implications for regional stratigraphic correlations. GeoArabia, Special Publication, 4: 4996. 
Schroeder, R., Schenk, K., Cherchi, A. \& Schwizer, B., 2007. Sur la présence de grands foraminifères d'âge Aptien supérieur dans l'Urgonien de la Nappe du Wildhorn (Suisse centrale). Note préliminaire. Revue de Paléobiologie, 26 (2): 665-669.

Simmons, M., 2020. Comments on "Facies modeling of synchronous successions - A case study from the mid-cretaceous of NW Zagros, Iran" by Shoghi et al., J. Afr. Earth Sci., 162 (2020) 103696. Journal of African Earth Sciences, 170: 103902.

Zhang, B.G., 1982. Orbitolina (Foraminifera) from Xizang. In: The series of the scientific expedition to the Qinghai-Xizang (Tibet) Plateau, Paleontology of Xizang(Tibet), 4. Science Press, Beijing: 51-80 (in Chinese with English abstract).
Zhang, B.G., 1986. Early Cretaceous Orbitolinids from Xainza and Baingoin, Xizang. Bulletin of Nanjing Institute of Geology and Palaeontology, Academia Sinica, 10: 101-122 (in Chinese with English abstract).

Zhang, B.G., 1991, Cretaceous larger foraminifera orbitolines from Ngari, Western Xizang (Tibet) in Sun, D.L. et al. (eds.), Stratigraphy and palaeontology of Permian, Jurassic and Cretaceous from the Rutog region, Xizang (Tibet): Nanjing University Press, Nanjing, p. 68-87 (in Chinese with English abstract). 